Anuario de la Facultad de Derecho. Universidad de Extremadura 36 (2020): 797-825 ISSN: 0213-988X - ISSN-e: 2695-7728

\title{
LEGAL PROTECTION FOR INDONESIAN MIGRANT WORKERS WHO COMMIT CRIMINAL ACT ABROAD VIEWED FROM LEGAL PERSPECTIVE IN INDONESIA
}

\author{
PROTECCIÓN LEGAL PARA LOS TRABAJADORES MIGRANTES \\ INDONESIOS QUE COMETEN UN ACTO PENAL EN EL EXTRANJERO \\ VISTO DESDE LA PERSPECTIVA LEGAL EN INDONESIA
}

NURIANTO RACHMAD SOEPADMO Mahendradatta University

Recibido: 11/09/2020 Aceptado: 18/12/2020

\section{ABSTRACT}

This study aimed to determine how the legal protection of Indonesian Migrant Workers if they were involved in criminal cases abroad where the migrant workers works. This research was a qualitative research with a normative juridical approach. The method used in this research was the literature review method. The data obtained were then analyzed descriptively. Based on the research results, it was stated that there were still many cases of persecution by Indonesian Migrant Workers in the countries where they work. This resulted in the migrant workers being caught in a legal case in that country because of the human instinct to protect himself. Based on International Law and also National Law in Indonesia, especially laws related to the protection of Indonesian Migrant Workers, migrant workers must be protected. In Law Number 18 year 2017 concerning Protection of Indonesian Migrant Workers, it has been stated that Indonesian Migrant Workers and their families get protection from before working in the form of administrative and technical protection, protection during work and protection after work. 
Keywords: criminal, Indonesia law, International Law, migrant workers.

\section{RESUMEN}

El objetivo de este estudio es valorar la protección legal de los trabajadores migrantes indonesios ante el supuesto de que incurran en responsabilidad penal en el extranjero. Se trata de una investigación cualitativa con un enfoque jurídico normativo. Los datos obtenidos se han analizado de forma descriptiva. Sobre la base de los resultados de la investigación, se puede concluir que existen muchos casos de persecución por parte de trabajadores migratorios indonesios en los países donde trabajan. De acuerdo con el Derecho Internacional y también con la legislación nacional de Indonesia, especialmente las leyes relacionadas con la protección de los trabajadores migrantes indonesios, los trabajadores migrantes han de ser protegidos. En la Ley número 18 del año 2017, relativa a la protección de los trabajadores migrantes indonesios, se ha establecido que los trabajadores migrantes indonesios y sus familias han de recibir protección antes de trabajar, durante el trabajo y después del trabajo, en forma de protección administrativa y técnica.

Palabras clave: Derecho penal, Derecho de Indonesia, Derecho Internacional, trabajadores migrantes.

Sumario. Introduction. 2. Research Methods. 3. Result and Discussion. 3.1. Juridical Study of Law in Indonesia On Migrant Workers. 3.2. International Law Perspectives on Legal Protection of Migrant Workers. 3.3. Analysis of Legal Protection for Indonesian Migrant Workers Who Commit Crime. 4. Conclusion.

\section{INTRODUCTION}

In the era of globalization, migration abroad is a common practice for some Indonesian citizens for certain purposes. The objectives of migration carried out by Indonesian citizens abroad include Indonesian Migrant Workers, professionals, students, entrepreneurs, religious affairs, and so on. The background of overseas migration was because of the economic background. Poverty and the gain of earning a higher income than at home are strong driving factors for 
increased migration of people abroad ${ }^{1}$. The multidirectional flow of labor migration has resulted in an increasing number of countries becoming the sender and recipient of legal and illegal migrants². Nonlabor Indonesian citizens who go abroad do not cause many problems compared to Indonesian workers. This is due to differences in educational and economic backgrounds3. According to the provisions of Article 1 of Law of the Republic of Indonesia Number 18 of 2017 concerning the Protection of Indonesian Migrant Workers Abroad, it states that Indonesian Migrant Workers are every Indonesian citizen who will, is currently, or has done work with wages outside the territory of the Republic of Indonesia4. Based on the above definition, what is meant by a migrant worker is someone who works abroad for a certain period of time based on a work agreement and receives wages. Based on the type of work, migrant workers can be divided into 2 (two) types, namely: informal migrant workers and formal migrant workers.

Working as an Indonesian Migrant Workers abroad was an option taken because of the lack of education and expertise and the difficulty of getting a job at home. Intending to improve their fortunes by looking for their fortune in other countries, it is not uncommon for migran workers to experience a number of problems while working. Based on data from the National Agency for the Placement and Protection of Indonesian Migrant Workers (BNP2TKI) for the 2018-2019 period, the following is data on the placement of Indonesian migrant workers.

1 Retno Kusniati, "Perlindungan Hukum Dalam Upaya Pemenuhan HAM Buruh Migran," Jurna Penelitian Universitas Jambi Seri HUmaniora 11, no. 1 (2009): 47-56.

2 Wayne Palmer and Antje Missbach, "Enforcing Labour Rights of Irregular Migrants in Indonesia," Third World Quarterly 40, no. 5 (2019): 908-925.

3 Peni Susetyorini, "Perlindungan Tenaga Kerja Indonesia ( Tki ) Di Luar Negeri Oleh Perwakilan Republik Indonesia," $M M H$ 39, no. 1 (2010): 65-77.

4 Negara Republik Indonesia, UU RI Nomor 18 Tahun 2017 (Indonesia, 2017). 
Table 1. Table of Indonesian Migrant Workers Numbers for 2017-2019

\begin{tabular}{|c|c|c|c|c|c|c|}
\hline \multirow[t]{2}{*}{ Month } & \multicolumn{3}{|c|}{2017} & \multicolumn{3}{|c|}{2018} \\
\hline & Formal & Informal & Total & Formal & Informal & Total \\
\hline January & 7.785 & 9.216 & 17.001 & 10.147 & 12.199 & 22.346 \\
\hline February & 8.929 & 10.813 & 19.742 & 8.500 & 11.002 & 19.502 \\
\hline March & 11.287 & 10.946 & 22.233 & 11.147 & 13.095 & 24.242 \\
\hline Total & 28.001 & 30.975 & 58.976 & 29.794 & 36.296 & 66.090 \\
\hline \multirow[t]{2}{*}{ Month } & \multicolumn{3}{|c|}{2019} & & & \\
\hline & Formal & Informal & Total & & & \\
\hline January & 10.041 & 13.287 & 23.328 & & & \\
\hline February & 8.582 & 8.994 & 17.576 & & & \\
\hline March & 12.524 & 10.634 & 23.158 & \multirow{2}{*}{\multicolumn{3}{|c|}{$\begin{array}{l}\text { Source: Indonesian Mig } \\
\text { cers Placement and Prote }\end{array}$}} \\
\hline Total & 31.147 & 32.915 & 64.662 & & & \\
\hline
\end{tabular}

Working in another country is not as easy as working in your own country. Indonesian Migrant Workers often get a number of problems while working, it is not uncommon for some migrant workers to go into criminal circles. Based on data obtained from Liputan 6.com, there are ten problems that are often complained of by Indonesian Migrant Workers, namely: unpaid wages, overstay, Indonesian Migrant Workers wants to be sent home, dies in the destination

5 PUSLITFO BNP2TKI, Data Penempatan Dan Pelindungan PMI Periode Maret 2019, vol. 1, 2020. 
country, Indonesian Migrant Workers fails to leave, disconnects from communication, Indonesian Migrant Workers is sick / hospitalized, violence from the employer, work not in accordance with the work agreement, not being sent home even though the work contract is over ${ }^{6}$. Several reasons why this happens, among others, migrant workers are often placed as the object of policy and are always blamed in all human migration problems. The low level of education is a justification for any problems that occur, Indonesian Migrant Workers which is illegal (unofficial) and does not have adequate expertise is a factor in the poor implementation of Indonesian Migrant Workers7.

The 1945 Constitution of the Republic of Indonesia guarantees that every Indonesian citizen has the same rights and opportunities without discrimination to obtain a decent job and livelihood. Work is a human right that must be upheld, respected and guaranteed to be upheld. But in fact, the various cases that have befallen Indonesian migrant workers show how little legal protection they get. Even though the Indonesian Government has issued Law Number 39 year 2004 concerning the Placement and Protection of Indonesian Workers Abroad which was revised into Law Number 18 year 2017 concerning the Protection of Indonesian Migrant Workers, Government Regulation No. 3 of 2013 concerning the Protection of Indonesian Workers Abroad, and has ratified the Migrant Workers Convention of 1990 through Law Number 6 year 2012. Manpower is one of the most basic aspects of the production system, economic growth and the prosperity of the nation ${ }^{8}$. This condition is a very contradictory condition, because on the one hand the PMI who is a migrant worker is seen as something that can increase the country's foreign exchange. Migrant workers are given the title of foreign exchange heroes, meaning those that bring profit to the country. They are also development heroes who have contributed to the

6 Dwi Nurseffi Wahyuni, "10 Masalah Yang Paling Sering Diadukan TKI Di Luar Negeri - Bisnis Liputan6,” Liputan6.Com.

7 Rahma Kusuma Wardani, Endah Pujiastuti, and Tri Mulyani, "Perlindungan Hukum Terhadap Hak-Hak Pekerja Migran : Studi Kasus Satinah Sebagai Mantan TKI Di Arab Saudi," Humani (Hukum dan Masyarakat Madani) 5, no. 3 (2019): 38-49.

8 Henny Nuraeny, "Trafficking of Migrant Workers in Indonesia: A Legal Enforcement and Economic Perspective of Prevention and Protection Efforts," European Research Studies Journal 20, no. 4 (2017): 16-26. 
development of the nation and state. The economic contribution generated by migrant workers in the form of remittances to sending countries and economic contributions in the form of taxes to recipient countries is very large9. However, on the other hand they do not get protection for their human rights. Supposedly with the issuance of Law Number 39 year 2004 concerning the Placement and Protection of Indonesian Workers Abroad, Government Regulation Number 3 Year 2013 concerning the Protection of Indonesian Migrant Workers Abroad, and the ratification of the 1990 Migrant Workers Convention through Law Number 6 Year 2012, Indonesia's bargaining position will be stronger to push for protection to countries receiving Indonesian migrant workers. Various policies that regulate Indonesian Manpower must be harmonized so that they can run as much as possible, and must refer to the standard standards in Law No. 6 of 2012. The next step, the Government must prepare supporting infrastructure so that this law can be properly implemented.

When Indonesian Migrant Workers commits an action against the law to an extent (overmacht) abroad, the state should be able to protect the rights possessed by migrant workers as Indonesian citizens despite their status as a suspect or convict. Every Indonesian Migrant Workers has the right to obtain legal protection based on the provisions of the law. Legal protection is an effort to protect someone's interest by allocating a power to him to act in the said interest. There are two kinds of legal protection, namely preventive legal protection and repressive legal protection. Legal protection for workers is a protection for the interests of Indonesian workers who work abroad. Based on Law Number 39 of 2004 concerning the Placement and Protection of Indonesian Workers Abroad in Article 1 point (4) states that: "Protection of Indonesian Migrant Workers is all efforts to protect the interests of prospective Indonesian Migrant Workers in realizing guaranteed fulfillment of their rights in accordance with laws and regulations, both before, during, and after work".

9 Koesrianti, "Perlindungan Hukum Pekerja Migran Penata Laksana Rumah Tangga (PLRT) Di Luar Negeri Oleh Negara Ditinjau Dari Konsep Tanggung Jawab Negara," Yustisia 4, no. 2 (2015): 245-268. 
The implementation of protection for Indonesian Migrant Workers includes several things, namely shelter, repatriation, including efforts to provide legal aid and assistance, rehabilitation / restoration of physical and psychological health, reintegration / reunification with their families or communities ${ }^{10}$. And efforts to empower the economy and education so that PMI does not get trapped again in the problems it has experienced. The cause of not being fully protected for migrant workers is the problem of the ratification of the Migrant Workers Convention, which is one of the multilateral international agreements. The Indonesian government has ratified the Migrant Workers Convention in Law Number 6 Year 2012. One of the considerations for this ratification step is that the Government has already signed the International Convention on the Protection of the Rights of All Migrant Workers and Members of Their Families in New York on September 22, 2004. Law Number 39 Year 2004 concerning the placement and protection of Indonesian workers abroad has weaknesses. One of them is that this Law focuses more on the issue of placement, this puts the aspects of protection and legal aid aside ${ }^{11}$. The shortcomings of Law Number 39 Year 2004 were later revised so that Law Number 18 Year 2017 which puts more emphasis on aspects of protection for migrant workers.

The inadequate protection of migrant workers is indicated by reports related to the imposition of the death penalty against PMI who have committed criminal acts in the country where they work. However, if it is traced back to the background of PMI doing this is not automatically from their own will, but the existence of torture and mistreatment that has been obtained for a very long time has resulted in rebellious behavior aimed at protecting oneself. And this attitude will ultimately affect the employer where PMI works and lead to employer reporting of criminal acts committed by PMI. If in this case PMI has been declared a suspect and sentenced to a criminal sentence, the government can protect PMI's rights through protection and legal assistance stipulated by law. From several cases that

10 Susetyorini, "Perlindungan Tenaga Kerja Indonesia ( Tki ) Di Luar Negeri Oleh Perwakilan Republik Indonesia.”

11 Atik Krustiyati, "Optimalisasi Perlindungan Dan Bantuan Hukum Pekerja Migran Melalui Promosi Konvensi Pekerja Migran Tahun 200o,” Jurnal Dinamika Hukum 13, no. 1 (2013): 136-147. 
have occurred, especially in the case of PMI which was sentenced to death, with the government's diplomacy it was successful to save PMI from the death penalty by compensating the sentence in the form of paying a number of fines. With the existence of diplomatic law and international law regarding the protection of the rights of migrant workers, the government should be able to maximally protect Indonesian citizens, especially those with PMI status if they are caught in criminal cases. Based on this explanation, the purpose of this paper is to find out the legal protection of Indonesian workers who commit criminal acts abroad from the perspective of the applicable law in Indonesia.

\section{RESEARCH METHODS}

This research is a qualitative research with a normative juridical approach. The juridical normative used in this research is to study, analyze and interpret theoretical matters which are theoretical in nature, which are operational approaches to legal principles in the form of conceptions, invitation regulations, views, legal doctrines and legal systems ${ }^{12}$. The objects studied in this research are all juridical aspects of the legal regulations that apply to criminal migrants abroad. The method used in this research is the pustaka study method. The literature study method is used to examine references and previous research related to the law applicable to migrant workers who have committed criminal acts abroad. The data that has been collected is then analyzed descriptively.

\section{RESULT AND DISCUSSION}

\subsection{JURIDICAL STUdY OF LAW IN INDONESIA ON MigRANT WORKERS}

In the regulatory function, the state intervenes directly by making regulations governing labor, so that employment is no longer part of private law but public law. For this reason, the government makes regulations regarding the

12 Nurianto Rachmad Soepadmo, "The Relevance of Islamic and Customary Law on Concerning of Domestic Violence in Bali's Case Study," Research, Society and Development 28, no. 2 (2020): 1-43. 
protection of workers who work abroad as outlined in Law Number 13 Year 2003 concerning Manpower, regulations on Indonesian workers abroad through Law Number 39 Year 2004 concerning the Placement and Protection of Indonesian Workers Abroad and then Indonesia ratified the 1990 UN Convention on the Protection of the Rights of Migrant Workers and Members of Their Families ${ }^{13}$. As a whole, the legal regulations governing Indonesian migrant workers are: the 1945 Constitution of the Republic of Indonesia, the opening of Paragraph IV, Law Number 1 Year 1982 concerning the Ratification of the Vienna Convention on Diplomatic and Consular Relations and the Vienna Convention on Consular Relations, Law Number 37 Year 1999 concerning International Relations, Law Number 24 Year 2000 concerning International Treaties, Law Number 39 Year 2004 concerning the Placement and Protection of Indonesian Migrant Workers Abroad (which has now been amended by Law Number 18 Year 2017 concerning Protection of Indonesian Migrant Workers), Law Number 12 Year 2006 concerning Citizenship, Law Number 21 Year 2007 concerning the Eradication of the Crime of Trafficking in Persons, Presidential Decree Number 108 of 2003 concerning the Organizational Structure of the Indonesian Representatives, Presidential Instruction Number 6 Year 2006 concerning the Placement and Protection Reform Policy TKI, Decree of the Minister of Foreign Affairs of the Republic of Indonesia Number 02 / ANlll / 2005/01 Year 2005 concerning the Organization and Work Procedure of the Ministry of Foreign Affairs, Decree of the Minister of Foreign Affairs of the Republic of Indonesia Number 06 / A / OTNl / 2004/o1 Year 2004 concerning the Organization and Work Procedures of Representatives Republic of Indonesia Abroad, and Indonesian Laws and Regulations and other relevant international laws and customs ${ }^{14}$.

According to Law Number 39 Year 2004 concerning the Placement and Protection of Indonesian Workers Abroad, the obligations of migrant workers are listed in Article 9. The existence of worker obligations as regulated in this

13 Atika Fauziati, "Perlindungan Hukum Bagi Tenaga Kerja Indonesia Yang Terpidana Mati Di Luar Negeri Dalam Peraturan Perundang-Undangan Di Indonesia," Kumpulan Jurnal Mahasiswa Fakultas Hukum (2015).

14 Salmon Abertnego Manurung and Nabitatus Sa'adah, "Hukum Internasional Dan Diplomasi Indonesia Dalam Perlindungan Tenaga Kerja Migran Indonesia" 2, no. 1 (2020): 1-11. 
Law is a reciprocal relationship between workers and employers. If the worker has fulfilled his obligations, then the worker can obtain his rights as a migrant worker. According to Law Number 39 Year 004 concerning the Placement and Protection of Indonesian Workers Abroad, article 8, every prospective Indonesian Worker or Indonesian Worker has the same rights and opportunities to:

a. Work overseas;

b. Receive the same rights, opportunities and treatment that other foreign workers obtain in accordance with the laws and regulations of the destination country;

c. Obtain legal protection in accordance with statutory regulations for actions that can degrade one's dignity as well as violations of the rights established in accordance with statutory regulations during overseas placement;

The labor rights above are a form of legal protection provided to workers. This legal protection must be fulfilled if the workforce has fulfilled its obligations. When a working PMI experiences difficulties, such as in cases that have occurred, the state should be obliged to provide protection for PMI, both legal and illegal. The Universal Declaration of Human Rights (UDHR) regulates respect for human rights and freedoms as the foundation of justice, freedom and peace. Protection of migrant workers is part of the right to work and the right to work which is a human right. This right is included in Article 23 of the Universal Declaration of Human Rights (UDHR) and Article 6 of the International Covenant on Economic, Social and Cultural Rights ${ }^{15}$. Protection of migrant workers is part of the right to work and the right to work which is a human right. This right is included in Article 23 of the Universal Declaration of Human Rights (UDHR) and Article 6 of the International Covenant on Economic, Social and Cultural Rights. In Law Number 39 of 2004, the Government of Indonesia is obliged:

15 Fauziati, "Perlindungan Hukum Bagi Tenaga Kerja Indonesia Yang Terpidana Mati Di Luar Negeri Dalam Peraturan Perundang-Undangan Di Indonesia." 
1. Ensuring the fulfillment of the rights of prospective migrant workers / migrant workers, whether departing through a migrant worker placement agency or departing independently;

2. Oversee the implementation of the placement of prospective Indonesian Migrant Workers;

3. Establish and develop an information system for the placement of prospective migrant workers abroad;

4. Make diplomatic efforts to ensure the fulfillment of the rights and protection of migrant workers optimally in the destination country; and

5. Providing protection to Indonesian Migrant Workers during the period before departure, during placement, and after placement.

6. Protection during the placement of Indonesian migrant workers abroad is carried out by providing legal assistance in accordance with local legal provisions and international customs, and / or defense of the fulfillment of rights in accordance with work agreements and / or local laws and regulations.

On October 25, 2017, through the DPR-RI Plenary Session, the Law on the Protection of Migrant Workers was finally promulgated into Law Number 18 Year 2017 concerning the Protection of Indonesian Migrant Workers. Law Number 18 Year 2017 is a revision of Law Number 39 Year 2004 concerning the Placement and Protection of Indonesian Migrant Workers Abroad. Law Number 18 Year 2017 concerning the Protection of Indonesian Migrant Workers has made many advances in several aspects. Among these are aspects of protection that have adopted the International Convention on the Protection of the Rights of Migrant Workers and Members of Their Families, which the Government of Indonesia has also ratified through Law Number 6 Year 2012. As for the consideration of the issuance of Law No. 18 of 2017 is:

a. that work is a human right that must be upheld, respected, and guaranteed to be upheld as mandated in the 1945 Constitution of the Republic of Indonesia; 
b. that the state guarantees rights, opportunities, and provides protection for every citizen without discrimination to obtain decent work and income, both at home and abroad in accordance with their expertise, skills, talents, interests and abilities;

c. that Indonesian migrant workers must be protected from human trafficking, slavery and forced labor, victims of violence, abuse, crimes against human dignity, and other treatment that violates human rights;

d. that the placement of Indonesian migrant workers is an effort to realize equal rights and opportunities for workers to obtain decent work and income, the implementation of which is carried out with due regard for dignity, human rights and legal protection, as well as equal employment opportunities and provision. workforce in accordance with national interests;

e. that the state is obliged to improve the entire protection system for Indonesian migrant workers and their families that reflects human values and dignity as a nation starting from before work, during work, and after work;

f. that the placement and protection of Indonesian migrant workers needs to be carried out in an integrated manner between government agencies, both central and regional by involving the community;

g. that the provisions stipulated in Law Number 39 of 2004 concerning the Placement and Protection of Indonesian Workers Abroad are no longer in accordance with the development needs for the protection of Indonesian migrant workers;

h. that based on the considerations as referred to in letter a, letter b, letter c, letter d, letter e, letter $\mathrm{f}$, and letter $\mathrm{g}$, it is necessary to establish a Law on the Protection of Indonesian Migrant Workers ${ }^{16}$.

16 Negara Republik Indonesia, UU RI Nomor 18 Tahun 2017. 
Law Number 18 Year 2017 emphasizes and gives a bigger role to the government and reduces the role of the private sector in the placement and protection of Indonesian Migrant Workers. This Law also provides Social Security protection for Indonesian Migrant Workers which has been implemented by insurance companies that are members of the insurance consortium with protection programs covering pre-placement, placement period and post-placement protection. This protection role is currently being transferred and implemented by the Social Security Administering Bodyin accordance with Law Number 40 Year 2004 concerning the National Social Security System and Law Number 24 Year 2011 concerning Social Security Administering Bodies. For certain risks that are not covered by the Social Security program, National Social Security System can work with government or private institutions.

The provisions governing the placement and protection of Indonesian Migrant Workers Abroad in Law Number 39 of 2004 concerning the Placement and Protection of Indonesian Migrant Workers Abroad have not fulfilled the needs for the Protection of Indonesian Migrant Workers. Law Number 39 of 2004 concerning the Placement and Protection of Indonesian Workers Abroad has not regulated the distribution of tasks and authorities between the Central Government, Regional Government and the private sector proportionally. In Law No. 18 of 2017, the duties and authorities of the Central Government, Local Government and the private sector have been described proportionally. In addition, details regarding the rights and obligations of migrant workers are also described in more detail and details on the protection of migrant workers are also added and in more detail. As for the protection of migrant workers based on Law Number 18 of 2017, namely:

1. Pre-Work Protection which consists of Administrative Protection and Technical Protection

2. Protection During Work

Protection during work (Article 21) includes at least:

a. data collection and registration by labor attaches or appointed foreign service officials; 
b. monitoring and evaluation of the employer, work and working conditions;

c. facilitate the fulfillment of the rights of Indonesian Migrant Workers;

d. facilitate the settlement of labor cases;

e. providing consular services;

f. assistance, mediation, advocacy, and provision of legal assistance in the form of facilitation of advocate services by the Central Government and / or Representatives of the Republic of Indonesia as well as guardianship in accordance with local state laws;

g. guidance for Indonesian Migrant Workers; and

h. facilitation of repatriation.

Protection of Indonesian Migrant Workers while working is carried out without taking over the criminal and / or civil responsibility of Indonesian Migrant Workers and is carried out in accordance with the provisions of laws and regulations, the laws of the country of placement destination, as well as international laws and customs. In the context of enhancing bilateral relations in the field of manpower and the protection of Indonesian Migrant Workers abroad, the Central Government shall determine the position of labor attaché at Representatives of the Republic of Indonesia in certain countries. The Manpower Attached is regulated by a Presidential Regulation. The procedure for providing protection during work is regulated by a government regulation.

\section{After Work Protection}

Protection after work as regulated in the law includes:

a. facilitation of return to their place of origin;

b. resolving the unfulfilled rights of Indonesian Migrant Workers;

c. facilitation of the management of Indonesian Migrant Workers who are sick and die;

d. social rehabilitation and social reintegration; and

e. empowerment of Indonesian Migrant Workers and their families ${ }^{17}$.

17 Ibid. 


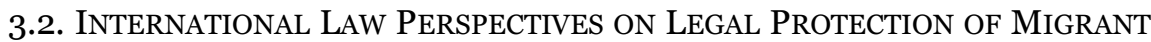
WORKERS

Protection of the rights of migrant workers according to international law, based on international agreements, both hard law and soft law. The source of international law relating to the rights of migrant workers based on international treaties when signed and ratified, the country legally has the obligation to implement and provide obligations to fulfill the rights of migrant workers in the country. International law states that a country has an obligation to protect citizens of that country who live abroad ${ }^{18}$. The term is in accordance with Diplomatic Protection; where the citizen wherever he is will get protection from his country. "Action taken by a state against another state in respect of injury to the person or property of national caused by an internationally wrongful act or omission attributable to the latter state" is concept of Diplomatic Protection $^{19}$. Meanwhile, international law relating to the protection of human rights and the rights of migrant workers is as follows:

\section{The 1948 Universal Declaration of Human Rights}

The Universal Declaration of Human Rights (UDHR) states that everyone has the right to work, has the right to freely choose work, has the right to just and favorable conditions of work and is entitled to protection from unemployment. Everyone, without discrimination, has the right to equal pay for equal work. Every person who works has the right to a just and profitable wage, which guarantees a dignified life for himself and his family, and if necessary supplemented with other social protection. And everyone has the right to establish and enter trade unions to protect their interests.

\section{International Convention on Economic, Social and Cultural Rights}

To support the fulfillment of the right to work, Article 6 of the International Covenant on Economic, Social and Cultural Rights (ICESCR) explains as follows

18 Anthony Aust, Handbook of International Law (Cambridge University Press., 2010).

19 Craig Forcese, "The Capacity to Protect: Diplomatic Protection of Dual Nationals in the "War on Terror," European Journal of International Law 17, no. 2 (2006): 369-394. 
"that states parties to this Covenant recognize the right to work, including the right to work. all persons have the opportunity to earn a living through work which he freely chooses or accepts, and will take adequate steps to protect this right. " Whereas paragraph 2 states that "The steps to be taken by the States Parties to this Covenant to achieve the full realization of this right, shall include technical and vocational guidance as well as training programs, policies and techniques to achieve economic, social development. and a stable culture and full and productive employment, with conditions which guarantee fundamental political and economic freedom for individuals. "

3. The 1990 International Convention on the Protection of the Rights of Migrant Workers and Members of Their Families

Indonesia is currently a signatory to the convention and has ratified it through Law of the Republic of Indonesia Number 6 of 2012 concerning Ratification of the International Convention on The Protection Of The Rights Of All Migrant Workers And Members of Their Families 1990 (International Convention Concerning the Protection of the Rights of All Workers Migrants and Family Members 1990). The main principle in this convention is the principle of nondiscrimination as stated in Article 7 which states that the Contracting States, in accordance with international human rights instruments, to respect and ensure that all migrant workers and members of their families are within their territory or who are subject to it. in its jurisdiction, in order to obtain the rights regulated in this convention without any distinction such as gender, race, color, language, religion or belief, political or other opinion, nationality, ethnic or social origin, nationality, age, economic position, wealth, marital status, birth status or other status.

\section{International Labor Organization (ILO) Conventions}

These two conventions outline the same matters as the 1990 International Convention on the Protection of the Rights of Migrant Workers and Members of Their Families. This ILO convention relating to migrant workers has not been ratified by Indonesia. so that it is not binding on Indonesia to provide treatment 
for migrant workers or foreign workers who work in Indonesia and Indonesian migrant workers who will work abroad.

5. ASEAN Declaration on the Protection and Promotion of the Rights of Migrant Workers

The ASEAN Declaration on the Protection and Advancement of the Rights of Migrant Workers dated January 13, 2007, states that both receiving and sending countries will strengthen the political, economic and social pillars of the ASEAN community by advancing the full potential and dignity of migrant workers in a climate of freedom, justice and stability in accordance with laws and regulations and policies of each ASEAN member country. Receiving countries and sending countries for humanitarian reasons cooperate to resolve cases of migrant workers who through no fault of their own then result in undocumented. Receiving and sending countries should take into account the basic rights and dignity of migrant workers and members of their families who have settled with them without undermining the implementation of the laws, regulations and policies of the receiving country ${ }^{20}$.

There are 3 (three) conditions that must be met in implementing diplomatic protection for citizens, in this case migrant workers, namely:

1. An International Wrong, that is, citizens of a country abroad must be given protection by their country of origin in the event of a violation of international law committed by the citizen of that country.

2. Exhaustion of Local Remedies, namely the state provides legal assistance to its citizens who are abroad to sue another country if that citizen has taken local legal action in the recipient country.

3. Link of Nationality, namely, diplomatic protection is given to citizens in the event of an act of violation of international law by another country ${ }^{21}$.

20 Naek Siregar and Ahmad Syofyan, "Perlindungan Hak Pekerja Migran Dalam Hukum Internasional Dan Implementasinya Di Indonesia” (1997): 147-170.

21 M. Suryono, E., \& Arisoendha, Hukum Diplomatik: Kekebalan Dan Keistimewaannya (Bandung: Angkasa, 1986). 
The terms that have been described are in accordance with the principle of passive citizenship. Passive citizenship in question is the jurisdiction of a country which applies to individuals who violate the law in the territory or jurisdiction of another country where the consequences of the violation of the law befall its citizens ${ }^{22}$. Therefore, the state as a place where the violation of the law occurs is incapable and unable to punish, then the country whose citizens are affected by the violation of the law has the authority to punish.

Legal protection for Indonesian workers, it is not enough to just use Indonesian laws and regulations because the work space for Indonesian workers is located abroad. So that the government needs to ratify international conventions related to legal protection for Indonesian workers so that they can provide maximum protection. A country, if it has not ratified the Migrant Workers Convention, means that the country has not been able to provide protection to its citizens as a form of state responsibility. Indonesia has ratified many international conventions and regulations, but there are still problems that arise regarding the insecure protection of Indonesian Migrant Workers working abroad, even though the problems are increasing and getting more complicated. This needs to be re-analyzed with great care. Whether domestic regulations are no longer in accordance with the development of problems that arise regarding PMI protection, or is it true that the Indonesian government has not fully implemented all national and international regulations regarding Indonesian Migrant Workers protection. The responsibility for the protection and fulfillment of all rights and freedoms contained in the Covenant on Civil Rights, this is the responsibility of the state, especially the states that are parties to the convention. The state's responsibility to provide this protection is one form of human securing. Whether or not human security can be implemented really depends on the presence or absence of good governance 23 .

22 Manurung and Sa'adah, "Hukum Internasional Dan Diplomasi Indonesia Dalam Perlindungan Tenaga Kerja Migran Indonesia.”

23 Krustiyati, "Optimalisasi Perlindungan Dan Bantuan Hukum Pekerja Migran Melalui Promosi Konvensi Pekerja Migran Tahun 2000.” 


\subsection{Analysis of Legal Protection fOR IndONESian Migrant Workers} WHO COMMIT CRIME

Indonesian Migrant Workers who commit crimes in the country where they work are entitled to legal protection from the country of origin of the Indonesian Migrant Workers. Especially if the reason behind the criminal act committed by PMI is as a form of self-defense for behavior that threatens his life. Based on Law Number 18 of 2017 article 3 states that the protection of Indonesian Migrant Workers aims to ensure the fulfillment and enforcement of human rights as citizens and Indonesian Migrant Workers; and ensuring legal, economic and social protection for Indonesian Migrant Workers and their families ${ }^{24}$. This shows that every migrant worker has the right to obtain legal protection guarantees in accordance with statutory regulations for actions that can degrading their dignity. One example of Indonesian Migrant Workers committing a criminal act is the Satinah case. Satinah was sentenced to death in Saudi Arabia for being accused of murdering her employer. Satinah's actions were not without reason. In the Satinah case, she received mistreatment from her employer. This is clear evidence that he has been deprived of his right to humane treatment. In this case, he should have the right to feel safe and the right to receive protection from the state against physical violence. Yet here, Satinah has fulfilled her obligations as a migrant worker, namely serving her employer 25.

Based on Law Number 18 Year 2017 article 6 paragraph 1 (g), it is stated that migrant workers receive protection and legal assistance for actions that can degrade their dignity and in accordance with the provisions of laws and regulations in Indonesia and in the destination country of placement ${ }^{26}$. Referring to RI Government Regulation Number 3 year 2013 concerning Protection of Indonesian Workers Abroad, this Government Regulation regulates Indonesian Migrant Indonesia protection starting from pre-placement, placement period to

24 Negara Republik Indonesia, UU RI Nomor 18 Tahun 2017.

25 Wardani, Pujiastuti, and Mulyani, "Perlindungan Hukum Terhadap Hak-Hak Pekerja Migran : Studi Kasus Satinah Sebagai Mantan TKI Di Arab Saudi.”

26 Negara Republik Indonesia, UU RI Nomor 18 Tahun 2017. 
post-placement. Protection during the placement period is provided by the Representative. The protection provided includes:

\section{Coaching and supervising Indonesian Migran Workers}

To reduce unexpected incidents such as cases of abuse of Indonesian Migran Workers, or Indonesian Migran Workers who are guilty by law, the government must provide supervision for Indonesian Migran Workers, business partners, and users.

\section{Provision of legal assistance}

If Indonesian Migrant Workers is hit by a legal problem, based on the existing law Indonesian Migrant Workers is entitled to legal assistance and legal assistance during the court process. This also applies if PMI experiences physical violence while working in the country of employment. The RI Representative works with lawyers to provide directions to Indonesian citizens who will face legal proceedings. This includes the country's local legal system, procedural law and advice on attitudes and behavior during the legal process that will influence court decisions. In this case the Representative will assist in solving the problem ${ }^{27}$.

\section{Defense for the fulfillment of Indonesian Migrant Workers' rights}

If in the case of Indonesian Migrant Workers that is dragged into legal issues related to violations of their human rights, the government is obliged to carry out prosecution for the fulfillment of their rights as PMI. If there is a violation of human rights acts, it will certainly be contrary to the agreed international law as written in the International Labor Organization (ILO) Convention. So if it is like in the case of Satinah, if it is proven that the employer treated Satinah improperly and violated her human rights, the employer can also be reported and prosecuted legally. Therefore, even though they are abroad, the protection of the rights of migrant workers is still regulated by international law.

27 Susetyorini, "Perlindungan Tenaga Kerja Indonesia ( Tki ) Di Luar Negeri Oleh Perwakilan Republik Indonesia.” 


\section{Diplomatic Efforts}

Diplomatic efforts in protecting Indonesian Migrant Workers are carried out through diplomatic channels in a peaceful manner and can be accepted by both parties which are coordinated by the minister responsible for foreign relations and foreign policy. Negotiations were carried out to find a way out so that the penalties against PMI could be mitigated in accordance with the reality of the problems that occurred. So with this negotiation, PMI is not the culprit who is absolutely guilty of the incident that occurred. As in the case of Satinah, with long negotiations, finally Satinah's death sentence can be replaced by paying a number of fines to the victim's family.

Protection of undocumented or illegal Indonesian labor migrants is also the government's responsibility. Indonesia, which is a State Party to the 1990 UN Convention on the Rights of All Migrant Workers and Their Families, this article shows that illegal migrant workers in this country have the legal right to protection against labor exploitation ${ }^{28}$. The efforts that have been made are the same, namely first to protect them with a political approach. The political approach is carried out in a concrete manner by the Government to seek protection of PMI abroad by making a cooperation agreement in the form of a Momerandum of Understanding (MoU), arrangement or bilateral agreement. The bilateral agreement on the placement and protection of Indonesian migrant workers is needed in order to optimize the protection of migrant workers who have problems abroad. This bilateral agreement can serve as a legal umbrella for Indonesian Representatives in resolving Indonesian Migrant Workers problems. Without the basis of a bilateral agreement, the Indonesian Representative's space for movement is limited to the 1963 Vienna Convention on Consular Relations. With the signing of a memorandum of understanding between the Government of Indonesia and the Government of the local country. aka the interests of TKI will be more protected ${ }^{29}$. Second, the establishment of the National Agency for

28 Palmer and Missbach, "Enforcing Labour Rights of Irregular Migrants in Indonesia."

29 Susetyorini, "Perlindungan Tenaga Kerja Indonesia ( Tki ) Di Luar Negeri Oleh Perwakilan Republik Indonesia." 
the Placement and Protection of Indonesian Workers (BNP2TKI), whose task is to carry out placements on the basis of a written agreement between the government and the government of the PMI user country or legal entity user in the destination country and provide services, coordinate and supervise: documents, provision of final departure (PAP), problem solving, sources of funding, departure to return, improving the quality of Indonesian Migrant Workers candidates, information, quality of PMI placement executors, and improving the welfare of PMI and their families. Third, the provision of humanitarian assistance to PMI who is undergoing a judicial process in their local country, due to allegations of having committed a criminal act. Fourth, provision of legal assistanceзo.

The constitutional state of Indonesia which is the basis as part of the effort to fulfill the constitutional rights of citizens in accordance with the fourth paragraph of the Preamble to the 1945 Constitution, which states explicitly that the goal of the Indonesian state is to create the welfare of the Indonesian people. The concept of the relationship between Indonesian national law relating to the placement and protection of Indonesian workers and international law through an international convention or agreement through the principle of the pacta sunt servanda in the government's commitment to international treaties signed by the theory of ratification or ratification of international agreements ${ }^{31}$. But in fact, there are still many Indonesian Migrant Workers who have not received maximum legal protection. Some of the factors causing the ineffective legal protection for Indonesian Migrant Workers sent abroad are as follows:

\section{The weakness of Indonesian diplomacy}

The role of diplomacy carried out by the Indonesian government, such as when there are problems with Indonesian Migrant Workers, is still lacking. This is also a common symptom in all Indonesian government diplomacy abroad, such as less proactivity, no breakthrough creations and less lobbying. Because

30 Nina Rosida, "Perlindungan Hukum Bagi Tenaga Kerja Indonesia Di Luar Negeri," Jurnal Muara Ilmu Sosial, Humaniora dan Seni 1, no. 1 (2017): 95-104.

31 Fatkhul Muin, "Perlindungan Hukum Terhadap Tenaga Kerja Indonesia (Tinjauan Terhadap UU Nomor 39 Tahun 2004 Tentang Penempatan Dan Perlindungan Tenaga Kerja Indonesia)," Jurnal Cita Hukum 3, no. 1 (2015). 
there are many problems for that have not received significant and comprehensive attention or advocacy.

2. Weak laws that guarantee Indonesian Migrant Workers with problems in the Destination Country System

Legal systems in foreign countries, especially trial processes that involve citizens

foreign countries including Indonesian Migrant Workers are known to be very slow. The average settlement of 1 (one) criminal case takes between 2 - 5 years, while for civil cases (labor disputes) it takes between 1 - 4 years. In the judicial system, the presence of Indonesian Migrant Workers is absolutely necessary during the trial process.

3. Difficulty in recording the presence of migrant workers in destination countries of the government

The government cannot confirm the number of Indonesian Migrant Workers who work abroad, especially in Malaysia, especially illegal Indonesian Migrant Workers, because they do not report their personal data to the Indonesian Embassy. So that if they are exploited by their employer or the company that hired them, the Indonesian Embassy will find it difficult to handle their cases.

\section{Existence of Indonesian Representatives Does not function optimally}

The existence of representatives of the Republic of Indonesia cannot function optimally because the format has not been designed in accordance with the national leadership or needs. Where the number of embassy and consulate staff is not proportional to the number of Indonesian citizens. This makes it difficult for embassy and consulate staff to monitor and serve all the needs of Indonesian citizens, including Indonesian Migrant Workers.

5. Lack of bilateral agreements between Indonesia and Indonesian Migrant Workers Destination Countries Abroad Without

Without a bilateral agreement, the Indonesian Representatives' movement in protecting their citizens is limited to the 1963 Vienna Convention and the 1961 
Vienna Convention. The Vienna Convention still tends towards absolutism from the authority of the receiving country. The general objective of the Vienna Convention is only to grant the sending country the right to communicate and engage with its nationals in the host country, thus limiting the sending countries' participation in providing protection to their citizens. In addition, there is no clarity regarding the limits included in the category of intervention on domestic policies in recipient countries.

6. Lack of Legal Awareness Level for Indonesian Migrant Workers Candidates

Based on the results of research on Indonesian Migrant Workers, it shows that the level of legal knowledge of prospective Indonesian workers on regulations related to placement and protection is still very low, namely only $20 \%$ know that the placement and protection of Indonesian Migrant Workers abroad is regulated by law, the rest $66,7 \%$ were unaware of the rule32. In addition to legal knowledge, the next indicator that needs to be understood in the study of legal awareness is legal understanding. Legal understanding is a number of information that a person has regarding the content of the law in question. Based on the research results, it is known that only 33.3\% of Indonesian Migrant Workers candidates know the contents of Law Number 39 Year 2004 and 66.7\% do not understand the contents of the law33. The understanding of the contents of the regulation is only limited to the placement procedure that states that working abroad must have fiscal documents, final provisioning and work visas, the rest such as job training, the job market does not know it.

\section{Weak Law Enforcement}

In labor law, law enforcement can be done administratively or criminally. Likewise, with Law Number 39 Year 2004 concerning the Placement and Protection of migrant workers Abroad, Article 100 states that the Minister imposes administrative sanctions for violations of several provisions as referred to in

32 Endar Susilo, "Rekonstruksi Perlindungan Hukum Tenaga Kerja Tentang Penempatan Dan Perlindungan Tenaga Kerja,” Jurnal Ilmiah Ilmu Hukum QISTIE 9, no. 39 (2016): 155-175.

33 Ibid. 
Article Administrative Sanctions in the form of written warnings, temporary suspension of part or all of the activities. efforts to place PMI, revocation of permits, cancellation of departure for Indonesian Migrant Workers candidates, and / or to return Indonesian Migrant Workers from abroad at their own expense. However, in its implementation several violations of these provisions were committed by Implementing the Placement of Indonesian Private Workers but were not subject to administrative.

\section{Weak Overseas PMI Supervision System}

In Article 92 paragraph (1) of Law Number 39 Year 2004 states that supervision of the implementation of the placement and protection of every Indonesian worker in the country is carried out by the agencies responsible for manpower affairs in the Central Government, Provincial Governments and Regency / City Governments. Meanwhile, supervision of the implementation of placement and protection of Indonesian workers abroad is carried out by representatives of the Republic of Indonesia in destination countries.5 Currently, the Indonesian government only has 13 Labor Attaches (Atnaker) in placement countries, namely Hong Kong, Malaysia, Singapore, South Korea, Brunei Darussalam, Saudi Arabia (Riyadh and Jeddah), Kuwait, Qatar, United Arab Emirates (UAE), Taiwan, Syria, and Jordan. The labor attaché has labor service duties which include protection and data collection in the country of placement, monitoring its existence, assessing business partners or agents in processing Indonesian Migrant Workers documents, PMI advocacy efforts, legalizing work agreements or contracts and fostering Indonesian Migrant Workers who have been placed 34 .

So far, the supervision of representatives of the Indonesian government abroad tends to only implement protection when there are problems with workers whose reports are submitted to the supervisory officers of the Indonesian Consulate General / the Indonesian Embassy. The preventive measures mandated by Law Number 39 Year 2004 are still not being implemented. This is also

34 Ibid.

Anuario de la Facultad de Derecho. Universidad de Extremadura 36 (2020): 797-825 ISSN: 0213-988X - ISSN-e: 2695-7728 
due to the inadequate supervision system established by the government. Reflecting on the labor inspection system abroad from several countries such as the Philippines and Australia, the government should collect data on the placement and location of each Indonesian / female worker so that overseas supervisors can at any time monitor the fulfillment of workers' rights. PMI in every house where the PMI works. In addition, the limitations of labor inspectors abroad are also an obstacle to the effectiveness of supervision so far. The high increase in the number of female workers, especially domestic workers who work in several destination countries, such as Saudi Arabia, Malaysia, Singapore, Taiwan, South Korea, and Japan, has caused supervisors abroad who tend not to increase in number to be overwhelmed in carrying out supervision. These supervisors should not only wait for reports, but periodically monitor the condition of fishery workers so that these preventive measures can prevent cases of violations experienced by workers in this field.

Everyone, including Indonesian Migrant Workers, has the right to recognition, guarantee, protection, and legal certainty that is just and equal treatment before the law. Every Indonesian Migrant Workers has the right to work and receive fair and proper compensation and treatment in an employment relationship. The right to life, the right not to be tortured, the right to freedom of thought and conscience, the right to religion, the right not to be enslaved, and the right not to be prosecuted on the basis of retroactive law are human rights that cannot be reduced under any circumstances and by anyone. In order for the national law on the protection of migrant workers to be maximally implemented, cooperation from all parties is required. Improving the mechanisms and regulations of Indonesian migrant workers as mandated by the Law on the Protection of Indonesian Migrant Workers and carrying out a data collection process on Indonesian migrant workers, hopefully it can reduce the incidence of Indonesian Migrant Workers abuse cases in the countries where they work, and the number of Indonesian Migrant Workers caught in criminal cases can be reduced. The government should continue to monitor the flow of labor migration by private labor agencies, as well as develop more access to job opportunities, especially for local workers, improve coordination and cooperation at the local, regional 
and international levels35. The state does not want an increase in the number of Indonesian citizens who are victims of mistreatment in foreign countries.

\section{CONCLUSION}

The 1945 Constitution of the Republic of Indonesia guarantees that every Indonesian citizen has the same rights and opportunities without discrimination to obtain a decent job and livelihood. Work is a human right that must be upheld, respected and guaranteed to be upheld. Indonesian Migrant Workers must be protected from human trafficking, including slavery and forced labor, victims of violence, abuse, crimes against human dignity, and other treatment that violates human rights. Protection of Indonesian Migrant Workers needs to be carried out in an integrated system that involves the Central Government, Local Government and the community. Migrant workers who are caught in criminal cases in the country where they work are entitled to legal assistance and assistance during the trial process. The government has a responsibility to protect its citizens in foreign countries. The efforts made by the government to Indonesian Migrant Workers who are caught in criminal cases are monitoring to minimize PMI cases that are entangled in criminal cases, prosecuting the fulfillment of to Indonesian Migrant Workers 's rights if the criminal case is motivated by persecution of to Indonesian Migrant Workers, making diplomatic efforts to reduce the sentence imposed on to Indonesian Migrant Workers in the country where they work.

The state, in this case the Ministry of Manpower, must work extra to escort all Indonesian migrant workers who are indeed registered as migrant workers in accordance with Law Number 18 Year 2017 concerning the Protection of Indonesian Migrant Workers. If there are still various cases where employers have problems, which in the end can cause Indonesian Migrant Workers to be caught in criminal cases and the worst thing is that cause Indonesian Migrant Workers gets the death penalty, then the state must make every effort to protect the

35 Nuraeny, "Trafficking of Migrant Workers in Indonesia: A Legal Enforcement and Economic Perspective of Prevention and Protection Efforts.” 
maximum so that our migrant workers do not become victims. This must be done immediately and must be done in a structured, systematic and massive manner by involving all existing stakeholders in collaboration with the local state government and also by involving Indonesian citizens and students in that country. This can be supported by making a new MoU or moratorium that is adjusted to the new Indonesian Migrant Workers Protection Law so that the countries where Indonesian migrant workers work also strive to assist and provide comprehensive supervision of Indonesian migrant workers and also employers who employ cause Indonesian Migrant Workers.

\section{REFERENCIAS BIBLIOGRÁFICAS}

Aust, Anthony. Handbook of International Law. Cambridge: Cambridge University Press, 2010.

Fauziati, Atika. "Perlindungan Hukum Bagi Tenaga Kerja Indonesia Yang Terpidana Mati Di Luar Negeri Dalam Peraturan Perundang-Undangan Di Indonesia.” Kumpulan Jurnal Mahasiswa Fakultas Hukum (2015).

Forcese, Craig. "The Capacity to Protect: Diplomatic Protection of Dual Nationals in the 'War on Terror." European Journal of International Law 17, no. 2 (2006): 369-394.

Koesrianti. "Perlindungan Hukum Pekerja Migran Penata Laksana Rumah Tangga (PLRT) Di Luar Negeri Oleh Negara Ditinjau Dari Konsep Tanggung Jawab Negara.” Yustisia 4, no. 2 (2015): 245-268.

Krustiyati, Atik. "Optimalisasi Perlindungan Dan Bantuan Hukum Pekerja Migran Melalui Promosi Konvensi Pekerja Migran Tahun 200o." Jurnal Dinamika Hukum 13, no. 1 (2013): 136-147.

Kusniati, Retno. "Perlindungan Hukum Dalam Upaya Pemenuhan HAM Buruh Migran." Jurna Penelitian Universitas Jambi Seri HUmaniora 11, no. 1 (2009): 47-56.

Manurung, Salmon Abertnego, and Nabitatus Sa'adah. "Hukum Internasional Dan Diplomasi Indonesia Dalam Perlindungan Tenaga Kerja Migran Indonesia” 2, no. 1 (2020): 1-11.

Muin, Fatkhul. "Perlindungan Hukum Terhadap Tenaga Kerja Indonesia (Tinjauan Terhadap UU Nomor 39 Tahun 2004 Tentang Penempatan Dan Perlindungan Tenaga Kerja Indonesia)." Jurnal Cita Hukum 3, no. 1 (2015).

Negara Republik Indonesia. UU RI Nomor 18 Tahun 2017. Indonesia, 2017. 
Nuraeny, Henny. "Trafficking of Migrant Workers in Indonesia: A Legal Enforcement and Economic Perspective of Prevention and Protection Efforts." European Research Studies Journal 20, no. 4 (2017): 16-26.

Palmer, Wayne, and Antje Missbach. "Enforcing Labour Rights of Irregular Migrants in Indonesia." Third World Quarterly 40, no. 5 (2019): 908-925.

PUSLITFO BNP2TKI. Data Penempatan Dan Pelindungan PMI Periode Maret 2019. Vol. 1, 2020.

Rosida, Nina. "Perlindungan Hukum Bagi Tenaga Kerja Indonesia Di Luar Negeri.” Jurnal Muara Ilmu Sosial, Humaniora dan Seni 1, no. 1 (2017): 95-104.

Siregar, Naek, and Ahmad Syofyan. "Perlindungan Hak Pekerja Migran Dalam Hukum Internasional Dan Implementasinya Di Indonesia” (1997): 147-170.

Soepadmo, Nurianto Rachmad. "The Relevance of Islamic and Customary Law on Concerning of Domestic Violence in Bali's Case Study.” Research, Society and Development 28, no. 2 (2020): 1-43.

Suryono, E., \& Arisoendha, M. Hukum Diplomatik: Kekebalan Dan Keistimewaannya. Bandung: Angkasa, 1986.

Susetyorini, Peni. "Perlindungan Tenaga Kerja Indonesia ( Tki ) Di Luar Negeri Oleh Perwakilan Republik Indonesia." MMH 39, no. 1 (2010): 65-77.

Susilo, Endar. "Rekonstruksi Perlindungan Hukum Tenaga Kerja Tentang Penempatan Dan Perlindungan Tenaga Kerja.” Jurnal Ilmiah Ilmu Hukum QISTIE 9, no. 39 (2016): 155-175.

Wahyuni, Dwi Nurseffi. “10 Masalah Yang Paling Sering Diadukan TKI Di Luar Negeri Bisnis Liputan6." Liputan6.Com.

Wardani, Rahma Kusuma, Endah Pujiastuti, and Tri Mulyani. "Perlindungan Hukum Terhadap Hak-Hak Pekerja Migran : Studi Kasus Satinah Sebagai Mantan TKI Di Arab Saudi." Humani (Hukum dan Masyarakat Madani) 5, no. 3 (2019): 38-49.

Nurianto Rachmad Soepadmo Faculty of Law Mahendradatta University, Indonesia nuriantors30@gmail.com https://orcid.org/oooo-0001-8648-2183 
